\title{
Antiviral Activity of Chitosan Nanoparticles Encapsulating Curcumin Against Hepatitis C Virus Genotype 4a in Human Hepatoma Cell Lines [Corrigendum]
}

Loutfy SA, Elberry $\mathrm{MH}$, Farroh $\mathrm{KY}$, et al. Int $J$ The authors apologize for this error and advise it does not Nanomedicine. 2020;15:2699-2715.

The authors have advised Figure 8 on page 2712 is incorrect. The correct Figure 8 is shown below.

A

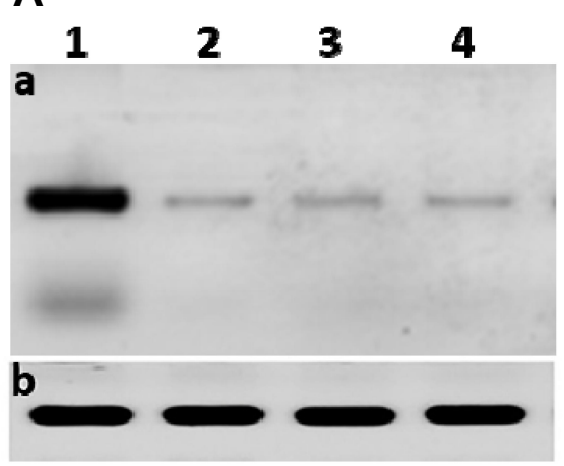

B

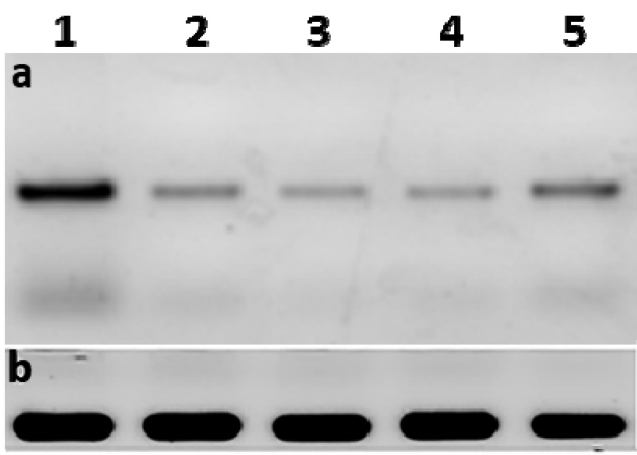

Figure 8 (A) The scanned densitometry Western blot of viral replication in Huh7 (a) versus $\beta$-actin (b); lane I, protein levels of infected untreated cells: lane 2, infected cells treated with curcumin: lane 3, infected cells treated with CsNPs: lane 4, infected cells treated with curcumin chitosan nanocomposite. (B) The scanned densitometry western blot of viral entry (a) versus $\beta$-actin (b) protein levels in positive; lane I, untreated infected cells: lane 2, cells treated with curcumin: lane 3, cells treated with CsNPs: lane 4 , cells treated with curcumin chitosan nanocomposite: lane 5 , cells treated with sofosbuvir. HCV core protein at size of 22 KD.

\section{Publish your work in this journal}

The International Journal of Nanomedicine is an international, peerreviewed journal focusing on the application of nanotechnology in diagnostics, therapeutics, and drug delivery systems throughout the biomedical field. This journal is indexed on PubMed Central, MedLine, CAS, SciSearch ${ }^{\mathbb{R}}$, Current Contents ${ }^{\mathbb{B}} /$ Clinical Medicine,

Journal Citation Reports/Science Edition, EMBase, Scopus and the Elsevier Bibliographic databases. The manuscript management system is completely online and includes a very quick and fair peer-review system, which is all easy to use. Visit http://www.dovepress.com/ testimonials.php to read real quotes from published authors. 